\title{
Climbing the Weiquan Ladder: A Radicalizing Process for Rights-Protection Lawyers
}

Fu Hualing* and Richard Cullen ${ }^{\dagger}$

\begin{abstract}
It is commonly acknowledged that weiquan lawyers operate in a narrow space, and lawyers with a radical stance work within a harsh environment. Weiquan lawyers advance and retreat in response to the changing macro-political-legal environment, but there is no sign that they are giving up their legal struggles. A steadily growing number of weiquan lawyers are tending to become more radical in their approach as their experience advances. This article studies the process in which weiquan lawyers start and sustain weiquan lawyering in a harsh environment and the factors that contribute to the radicalizing process. Its principal purpose is to identify and explain a radicalization process in which a lawyer climbs up the ladder of weiquan lawyering, from a moderate lawyer providing legal aid in individual cases to a critical or radical lawyer.
\end{abstract}

An authoritarian state prohibits political participation that poses a direct challenge to the regime. It turns out, however, that such a state may at the same time promote, or at least tolerate, a degree of rule of law. ${ }^{1}$ This development of legal possibilities under political constraints provides both the necessity and opportunities for political lawyering in which lawyers channel political challenges through a legal process. Where oppositional politics is prohibited or constrained, lawyers and other rights advocates may strive to seek legal remedies for their political claims.

There are many inherent political constraints in the operation of China's authoritarian state. Political participation remains tightly controlled under Chinese Communist Party (CCP) rule and as a result aggrieved citizens can rarely air and solve their problems through this route. The lack of effective venues for conventional political participation, however, is compensated in part by the development of certain legal institutions. In the past three decades, the CCP

\footnotetext{
* The University of Hong Kong. Email: hlfu@hku.hk (corresponding author).

+ The University of Hong Kong.

1 Tom Ginsburg and Tamir Moustafa, Rule by Law: The Politics of Courts in Authoritarian Regimes (New York: Cambridge Universeity Press, 2008).

(C) The China Quarterly, 2011 doi:10.1017/S0305741010001384
} 
has supplied a legal platform to address some of the political and social concerns in lieu of political participation.

Lawyers, especial weiquan (维权, rights-protection) lawyers, have taken up this opportunity. Weiquan lawyering refers to a legal and political process in which lawyers actively use legal institutions and other platforms to challenge China's authoritarian system. Weiquan is a flexible concept and it is difficult to identify who these lawyers are, especially given the varieties of weiquan lawyering. In a previous paper, we advanced a typology of moderate, critical and radical weiquan lawyers. Although lawyers move across these categories, the typology, it is argued, does provide a useful framework for understanding the phenomenon of weiquan lawyering in China. ${ }^{2}$ Moderate weiquan lawyering is closely associated with legal aid services and public interest litigation, with a focus on cases having lower political ramifications and aimed at improving the operation of the system. ${ }^{3}$ Such lawyers work within the legal framework and accept the existing political system. Radical weiquan lawyering, on the other hand, tends to take a more confrontational stance and regards the authoritarian system as the cause of the problem. Radical weiquan lawyers increasingly take an oppositional attitude and see themselves as working against the system and playing a transformative role. ${ }^{4}$

It is commonly acknowledged that weiquan lawyers operate in a narrow space, and those with a radical stance, in particular, work within a harsh environment. Some of them are occasionally detained and prosecuted, and others are subject to routine monitoring and harassment. Yet, despite the high risk, lawyers continue to challenge the political system through law and have become more resilient in defending and demanding legal rights. Weiquan lawyers advance and retreat in response to the changing macro-political-legal environment, but there is no sign that they are giving up their legal struggles. On the contrary, there is a continuous supply of young well-qualified lawyers who are willing to take up the challenge and have chosen and planned this career path. Moreover, a steadily growing number of weiquan lawyers tend to become more radical in their approach as their experience advances.

What motivates lawyers to start and sustain weiquan lawyering in a harsh environment, what are the factors that contribute to the radicalizing process, and how do lawyers who challenge the political system in China survive? This

2 For detailed discussion of this typology, see Fu Hualing and Richard Cullen, "Weiquan (rights protection) lawyering in an authoritarian state: building a culture of public-interest lawyering," The China Journal, No. 59 (2008), p. 111.

3 Existing literature tends to focus on moderate weiquan lawyering. See for example, Fu Hualing, "Access to justice and constitutionalism in China," in Stéphanie Balme and Michael W. Dowdle (eds.), Building Constitutionalism in China (Basingstoke: Macmillan, 2009); Mary E. Gallagher, "Mobilizing the law in China: 'informed disenchantment' and the development of legal consciousness," Law \& Society Review, Vol. 40, No. 4 (2006), p. 783; Benjamin L. Liebman, "Legal aid and public interest law in China," Texas International Law Journal, No. 34 (1999), p. 211; Ethan Michelson, "The practice of law as an obstacle to justice: Chinese lawyers at work," Law \& Society Review, Vol. 40, No. 1 (2006), p. 1.

4 Increasingly, weiquan lawyering is given a narrower interpretation to mean radical lawyering only. 
article attempts to answer these questions. Its principal purpose is to identify and explain a radicalization process in which lawyers climb up the ladder of weiquan lawyering, from moderate lawyers providing legal aid in individual cases to become critical or radical lawyers where, typically, using the legal system as a pivot, they challenge the authoritarian political system.

This article relies on extensive interviews of mainland weiquan lawyers carried out by one of the authors in Beijing, Hong Kong, Wuhan and Shenzhen from 2006 to 2009. Over the past four years, the author has interviewed nearly 40 weiquan lawyers and four activists in human rights NGOs through face-to-face interviews, telephone, emails and/or Skype. The authors contacted weiquan lawyers through a snow-balling process, a research methodology that is well suited for this sort of research. The community of weiquan lawyers is relatively small and close-knit. We first approached known weiquan lawyers and then asked them to identify others who might be willing to participate in the study.

\section{Climbing the Weiquan Ladder}

Entry points

There are multiple entry points to weiquan lawyering. Some lawyers are clearly motivated by a particular event, such as the generation of 1989. He Weifang 贺卫方, Zhu Jiuhu 朱久虎, Pu Zhiqiang 浦志强, Mo Shaoping 莫少平 and a few others became dedicated to political reform through law largely because of their personal experiences in the June Fourth Incident in 1989. ${ }^{5}$ Their political lawyering thus needs to be looked at within this context. There is also the generation of 2003 when lawyers and the public at large reacted passionately to the wrongful death of a young man named Sun Zhigang 孙志刚 who was initially detained by the police for failing to carry a proper identity card. Famous human rights advocates Teng Biao 滕彪 and Xu Zhiyong 许志永 made their debut by petitioning the national legislature to abolish a central government regulation authorizing the detention. ${ }^{6}$

Others became weiquan lawyers in response to a political opening in a particular field. A constitutional amendment in 2004 which provided for the constitutional protection of human rights led to the creation of a constitutional law and human rights committee in lawyers' associations at national and local levels. Lawyers such as Li Fangping 李方平 and $\mathrm{Wu}$ Ge 吴革 met their comrades-in-arms in that committee and used it as a platform to become weiquan lawyers. ${ }^{7}$ The famous handshake between Premier Wen Jiabao 温家宝 and an AIDS patient and the subsequent policy changes in this sensitive area provided

5 Lawyer interview, December 2006, BJ04.

6 Lawyer interviews, December 2006, BJ01 and BJ02.

7 Lawyer interviews, December 2008 and September 2009, HK11; March 2008, BJ12. 
opportunities for a group of dedicated young lawyers and advocates, such as Zhou Dan 周丹 and Li Dan 李丹, to offer their services in this field. ${ }^{8}$

Most weiquan lawyers, however, entered the field after going through an upward mobility process. As McCann points out: "Where radical challenges do occur, they usually begin with moderate demands concerning everyday issues framed in fairly traditional terms - such as demands for 'equal rights,' for fair treatment, or for safe conditions at work and in the general environment." 9 Chinese weiquan lawyers experience a similar process of development: they start their careers giving legal assistance in individual cases; they win cases because of their ability and dedication; their winning attracts attention from the press and the general public; and as a result they not infrequently receive government awards. Their success attracts more clients and more challenging cases. ${ }^{10}$ There is a process in which lawyers move up the ladder of political lawyering, gradually escalating their activism and becoming more critical and aggressive.

Few of the radical lawyers were political at the beginning of their legal careers; they are transformed by their legal experiences and became radical because of their sympathy for, and later identification with, their clients, and their frustration with the legal and political process. Lawyers like Gao Zhisheng 高智晟, Chen Guangcheng 陈光诚, Tang Jingling 唐荆陵, Zhang Xingshui 张星水, Li Boguang 李柏光, Jiang Tianyong 江天勇, Li Xiongbing 黎雄兵 and Yang Zaixin 杨在新 typically started by providing pro bono legal assistance and then encountered difficult cases. These were often cases with a degree of political sensitivity that mainstream lawyers were less likely to take.

Cases that were left to weiquan lawyers were hard to handle because the defendants were often powerful individuals, organizations or government departments. With a poor client, an abusive defendant and a weak court, lawyers were often confronted with seemingly insurmountable difficulties. Because of their determination, however, a number of weiquan lawyers did win what were regarded as unwinnable cases. This boosts their morale, and attracts positive media coverage and government attention. All this provides an incentive for lawyers to carry on.

It is interesting that many of the lawyers received government awards for their toughness and "waywardness" in pursuing the protection of rights of the poor and powerless. The courage to take on hard cases, toughness in battling injustice and the ability to win (in a court of law or in the court of public opinion, or sometimes both) naturally earn lawyers a good reputation which attracts government attention. The central government, having a vested interest in using the law to rein in abuse of power at the local level and to channel conflict through legal procedures, has seized the opportunity to promote moderate weiquan lawyering. It has offered awards to many of the lawyers who are tough, compassionate,

8 Lawyer interview, September 2009, HK21; NGO interview, March 2009, HK01.

9 Michael W. McCann, "How does law matter for social movement?" in Bryant G. Garth and Austin Sarat (eds.), How Does Law Matter? (Evanston: Northeastern University Press, 1998), pp. 88-89.

10 Li Weiping, "A rights defender who is forced to step out of school - record of the interview with prominent weiquan lawyer Teng Biao," Dongxiang (The Trend Magazine), April 2006, p. 66. 
dedicated and fearless in dealing with local abuses. Chen Guangcheng, Gao Zhisheng, Li Boguang and many others were hailed as model lawyers before they turned against the government. ${ }^{11}$ Similarly, the government and its press honoured Teng Biao and Xu Zhiyong for submitting their well-known petition to the National People's Congress calling for the abolition of the shelter and repatriation system that was used against migrants in cities. ${ }^{12}$ The People's Daily, the CCP's mouthpiece, twice publicized Hao Jinsong's 郝劲松 actions in filing a series of lawsuits against the Ministry of Railways and other high-ranking government offices for illicit fee-charging, and called for citizens to follow this example to seek legal protection of rights rationally. ${ }^{13}$ An important point is that there are many lawyers and advocates who are doing exactly what Chen Guangcheng and Gao Zhisheng did a few years ago before their direct confrontation with the government and the system. These young lawyers are continuing their moderate weiquan practice and are determined to use law to challenge the government. Numbers of them are highly likely to climb up the weiquan ladder and confront the system.

Ironically, it is the system that first helped ignite the hope for weiquan lawyers. Their initial success won them media and government support, and with such support they moved on to pick up more difficult cases. Encouraged by the prospect of success, they became more aggressive. As discussed below, it is the long process from witnessing the sufferings of the poor and the powerless, to sharing their frustration and helplessness and then to identifying with them that propelled weiquan lawyers take up a "weiquan identity." In the process, lawyers shifted from being the legal representatives of their clients to sharing a common identity and objectives. Once they have taken on the identity of the people they represent, most of the lawyers move on knowing well the risk that they face. The government creates its own challengers. Sooner or later, it has to face the often fearless, people-loving lawyers it has nurtured and promoted.

\section{Client radicalism}

Client demands have played an important role in the escalation of the conflict between weiquan lawyers and government institutions. The clients weiquan lawyers serve are not only desperate people suffering gross injustice, but also wayward citizens demanding remedies whatever it takes. Radicalism is highly visible across the board in China. Direct political challenges may be ruled out

11 "Law allows great passion, integrity save the world - interviewing lawyer Gao Zhisheng who represented many persons in numerous pro bono medical negligence cases," Zhongguo yiyao zhinan (China Medicine Guide), No. 4 (2003), p. 52.

12 The three professors who petitioned the NPC, namely Teng Biao, Xu Zhiyong and Yu Jiang, as a team, were elected as one of the top ten rule of law figures in China in 2003. "Counting the 'rule of law figures' in China in 2003," Zhongguo xinwen she (China News Service), 4 November 2003.

13 "My weiquan story, rationally defending rights leads to consensus," Renmin ribao (People's Daily), 13 April 2005, p. TMP07; and "The upgrading of the consumption structure leads to new changes in consumption and new topics in defending rights of consumers," Renmin ribao, 21 March 2006, p. 06. 
because of heavy-handed suppression, but radical activities are visible in less political issues, in which aggrieved citizens act (or react) forcefully when their more moderate approach in seeking justice fails to deliver. The cost of seeking legal remedies among vulnerable groups, such as migrant workers, is prohibitively high in terms of both time spent and expenses incurred. The barriers to justice have driven some of these desperate people to resort to violence and other radical measures. ${ }^{14}$ For many desperate people, legal remedies may be too late, can offer too little and are often ill-placed to bring real solutions.

Examples of social radicalism abound. Street vendors in China have been subject to systematic abuses by urban management officials. In 2006, Cui Yingjie 崔 英杰, a street vendor, killed an urban management officer who wanted to confiscate his small cart, the only source of his income. ${ }^{15} \mathrm{In}$ another incident, Zhou Yichao 周一超, like all Hepatitis B (HB) carriers, was prohibited from joining the civil service even though he did well in passing the civil servants' exam. He killed a recruitment official to vent his anger, and was sentenced to death. After Zhou was executed, his fellow HB carriers built a virtual shrine to commemorate him. ${ }^{16}$ More recently, in 2008, Yang Jia 杨佳, who was allegedly abused by the Shanghai police, murdered six police officers in a Shanghai police station. It is notable that Yang has been universally regarded as a national hero in the court of public opinion, even though he was sentenced to death for his crime. ${ }^{17}$

There have been increasing examples of more organized, and from time to time violent, resistance against the government. Thus, Shanwei 汕尾 peasants decided to fight against armed police with shovels to keep their land from government appropriation. They resorted to violence after witnessing the futility of law and non-violent means to settle disputes with the government in Taishi 太石. ${ }^{18}$ Similarly, in the more recent mass incidents in Guizhou, Hubei, Hunan and elsewhere, frustrated residents confronted police in violent ways. ${ }^{19}$ Lawyers have to face victims of environmental pollution who routinely take the law into their own hands and engage in confrontations with polluting factories by

14 Tong Lihua and Xiao Weidong, Zhongguo nongmingong weiquan chengben diaocha baogao (An Investigative Report on the Cost of Rights Protection by Chinese Peasants), available in Zhongguo lushi wang (The Website of All China Lawyers Association), 29 September 2005, http://www. chineselawyer.com.cn/pages/2005-9-29/s31553.html, accessed 17 February 2009.

15 For the details of this case, see "Tragedy exposed loopholes in law enforcement by urban management personnel - reflection on the case involving the stabbing of an urban management officer to death by a Beijing hawker," Xinxi ribao (Information Daily), 10 June 2007, p. 10.

16 HBVER xianquzhe: Zhou Yichao (wangshang jinianguan) (HBVER Pioneer: Zhou Yichao (Online Memorial Hall)), http://zhouyichao.netor.com/, accessed 18 February 2009.

17 For the details of Yang Jia's case, see "Full-text of the judgment of Yang Jia's first instance trial - no detailed explanation of his motive to commit crime," available in Yitong lushi guwen wang (Yitong Lawyers and Consultants Net), 11 September 2008, http://www.bj580.com/html/yitongzixun/20080911/ 179.html, accessed 18 February 2009.

18 For the details of the incident in Shanwei, see "Shanwei alleged villager who was defeated in an election incited people to riot," Ming bao (Mingpao Daily), 19 December 2005, p. A30.

19 See for example, Zhang Jieping, Zhu Yixin and Huang Lijian, "The hidden acute conflicts behind the riot in Guizhou," Yazhou zhoukan, Vol. 22, No 27 (2008), available in http:/www.yzzk.com/cfm/ Content_Archive.cfm?Channel=ae\&Path=2348282692/27aela.cfm, accessed 18 February 2009. 
cutting power lines, damaging machinery and picketing factories. Other cases have involved AIDS patients who threw tainted needles at riot police; and falun gong 法轮功 practitioners who protested against prosecution in silence. Migrant workers, unpaid pensioners and jobless veterans are ready and eager to use violence in asserting their claims when legal remedies are not forthcoming.

Lawyers are responding to these more aggressive civil society demands for rights. The result is growing radicalism amongst lawyers which reflects the growing radicalism in society. They are shaping and reinforcing each other. By the time clients meet their weiquan lawyers, the former have gone through the initial period of abuse and victimization and the subsequent neglect, indifference and hostility. They have little to lose. They are desperate and have (often unreasonably) high expectations of lawyers who are willing to take up their cases. Indeed, clients challenge their lawyers to push the limits and blame them for not doing enough. According to one lawyer, some clients say: "We are told that you are a rights protection law firm, but why don't you protect our rights?" Lawyers' technical explanations on legal matters, such as procedure, evidence and burden of proof, are not something that the wayward petitioners wish to hear. ${ }^{20}$

Few clients instruct their lawyers to exercise professional self-restraint in their advocacy. Many weiquan lawyers tell stories to the effect that, as much as they want to politicize cases and causes, they frequently have to hold their clients back, especially in cases involving a large number of plaintiffs, making the requirement of some restraint a precondition for agreeing to take on a case. ${ }^{21}$ Lawyers advise their clients not to take drastic action, and typically want to adopt a strategy so that they can proceed at the pace the lawyers feel is most sensible. Especially in sensitive cases, lawyers make an extra effort to hold clients back, urging them not to do anything that might complicate the legal battle. ${ }^{22}$ Well-known lawyers tried very hard not to give any impression that they are inciting social unrest. Otherwise, as one lawyer puts it, "they will make me suffer (zhengsi wo 整死我).”23

There is thus a combination of factors leading to increased legal aggressiveness: sympathy for the clients, meeting public expectations, and lawyers' own commitment to their clients' causes. Demands for rights by lawyers in China are increasingly aggressive in part because of the instructions and challenges of their clients. It is the clients who feel strongly about their rights and entitlements - be it the right to property, belief or personal freedom - when they are grossly violated. It is the clients, not the lawyers, who, in the first instance, are invoking constitutional rights and are holding the government to its rule of law rhetoric. Lawyers, including weiquan lawyers, respond to the demands of their clients by

20 Lawyer interview, March 2008, BJ11.

21 Lawyer interviews, June 2007, HK06 and September 2009, HK21.

22 Lawyer interviews, December 2006, BJ01 and BJ02.

23 Lawyer interview, April 2007, SZ01 
bringing their cases to the attention of a different audience after some legal repackaging. ${ }^{24}$ The clients in the difficult cases, such as underground church goers and falun gong practitioners, are veterans who are well-versed in formal legal rights but they need lawyers to use their professional and institutional advantage to advance these rights. They are as strategic as their weiquan lawyers, and they "use" their lawyers' capacity just as their lawyers "use" their cases. As long as there are clients who place strong demands, there will be lawyers who feel compelled to take an extra step forward. Lawyers are, often, only as liberal (and aggressive) as their clients are.

\section{Experiencing the law}

Lawyers' interaction with the legal system affects the extent to which they take on a more radical or more moderate identity. Given lawyers' commitment to use legal institutions to address injustice, the extent to which law is receptive to legal claims affects the faith of lawyers in law and their incentive to resort to legal institutions for future grievances. At an important macro-instrumental level, the rule of law is a conservative project that stabilizes society and legitimizes regimes. When it functions properly, a lawsuit is an excellent means to isolate social conflict and pre-empt much social unrest.

However, the Chinese legal system has been indifferent or hostile to weiquan lawyering in practice (notwithstanding official, in principle, support when it is seen to be good for stability). There is, first of all, a widespread suspicion and hostility towards weiquan lawyers, even the moderate ones. Weiquan lawyering is regarded as somehow "deviant" within the mainstream legal profession and treated with suspicion. Judges, government officials and fellow lawyers routinely question lawyers' motive in taking up cases that allegedly disturb stability. Leading lawyers who are otherwise liberal-minded reformers not only question weiquan lawyers' competence but also challenge their integrity. ${ }^{25}$ Law firms are reluctant to retain lawyers who are active in weiquan lawyering because they often attract too much publicity and government attention. ${ }^{26}$

It is therefore not surprising to witness hostility and systematic abuse from legal institutions towards weiquan lawyers. It has been widely reported that local and central government departments in China prohibit or severely limit legal representation in political and other so-called sensitive cases, with the effect

24 This is of course not to deny that some radical lawyers incite clients to demonstrate against the government; insist on a not-guilty plea against the will of the clients; and insist on sacrificing the "small interest" of their clients for a "greater interest." Lawyer interview, June 2007, BJ05.

25 Lawyer interview, April 2008, WH01.

26 For example, Yang Zaixin was dismissed by his law firm in 2006 because of his provision of legal representation to falun gong followers; and the law firm with which Tang Jingling and Guo Yan worked terminated its contracts with the two lawyers one month before the contracts expired because of their provision of legal assistance to villagers in the Taishi incident. "Two weiquan lawyers work hand in hand to appeal for the people," Ming bao, 25 February 2006, p. A16. 
that meaningful defences are rendered impossible. ${ }^{27}$ Government officials often try to persuade or threaten people concerned with a sensitive case not to seek any legal assistance, or try to persuade their lawyers not to take up the case. Pressure can be applied to clients and their lawyers directly, but it is done more frequently and effectively through clients' workplaces and lawyers' law firms and the relevant government office. ${ }^{28}$ Where persuasion fails to deter lawyers, local authorities may try to prohibit them from physically entering certain places or meeting clients. Police may abuse lawyers, verbally and physically (sometimes by using local thugs), or place them under detention for interrogation. ${ }^{29}$ Police are known to monitor weiquan lawyers closely. They intercept telephone calls and emails and shadow them throughout the process of doing their work. ${ }^{30}$

When direct threats fail, the Bureau of Justice is mobilized to give warnings to lawyers and their law firms. This was a common strategy used to stop lawyers from representing cases relating to the 2008 milk scandal: law firm partners were called to attend meetings with Bureaus of Justice and were not permitted to leave unless they could guarantee that none of their lawyers would be involved in the relevant cases. ${ }^{31} \mathrm{~A}$ more direct threat is to delay or refuse the annual renewal of a practising licence, effectively stopping the lawyers from engaging in legal practice. The Bureaus of Justice have from time to time suspended or closed law firms on dubious grounds. ${ }^{32}$

The courts may also display little respect for law and legal procedures when they are "in conflict" with weiquan lawyers. It is well known that courts unlawfully set barriers to stop sensitive cases from entering the judicial process. They not only refuse to accept cases and refuse to disclose the reasons for rejection, but also refuse to confirm the rejection in writing, thus depriving lawyers of any opportunity to appeal against the decision. ${ }^{33}$ Even when a case is accepted, the court may limit public observation in public trials; limit lawyers' rights in making submissions; and totally disregard lawyers' arguments. ${ }^{34}$ Courts are known in many cases to have made a mockery of their own process.

One consequence of legal hostility to weiquan cases is that most lawyers practise self-censorship and refrain from touching cases they know may draw hostile official responses. According to lawyers from Shanghai, no lawyers are willing

27 Fu Hualing, "When lawyers are prosecuted ... the struggle of a profession in transition," Journal of Comparative Law, Vol. 2, No. 2 (2007) p. 95.

28 For examples of pressure from lawyers' law firms, see the cases mentioned in $\mathrm{n}$. 26. Lawyer interviews, April 2008, WH02 and WH03.

29 Fu Hualing, "When lawyers are prosecuted"; lawyer interviews, June 2007, BJ06 and December 2006, BJ01.

30 Lawyer interview, June 2007, HK06.

31 Lawyer interviews, April 2008, HK01 and HK02.

32 Lawyer interviews, December 2006 and September 2009, HK04; NGO interviews, April and June 2009, HK02.

33 "Courts have to act according to the legal procedure when refusing to accept claims against Sanlu," Nanfang dushi bao (South Metropolitan Daily), 1 November 2008, p. A02.

34 "Yang Jia was sentenced to death for killing six police officers, Shanghai court announced the judgement in camera, the defendant did not say a word," Ming bao, 2 September 2008, p. A21. 
to take on land appropriation cases in the whole of Shanghai after the persecution of lawyer Zheng Enchong 郑恩宠 for "leaking state secrets." 35 Political dissidents typically experience difficulties in finding lawyers who are willing to defend their cases with vigour. Lawyers like Mo Shaoping, Zhang Sizhi 张 思之, Teng Biao and a few others have represented most of the political dissidents and other lawyers in trouble. The weiquan community is acutely aware of this shortage and is actively encouraging and nurturing younger lawyers to support the cause. Unfortunately, a hostile and repressive atmosphere ensures that the vast majority tend to stay away from any weiquan lawyering, even in moderate cases.

Another consequence of the hostility, however, is the creation of a group of lawyers who are even more energized to challenge the system. The injustice they witnessed and suffered and the indifference and hostility they encountered "fired them up." Routine harassment makes regular lawyering impossible and as a consequence frustrates and radicalizes lawyers. As mentioned above, many lawyers who entered the field at the lower end of the political spectrum are fighters; strong-minded people who will not easily give up their causes. Frustration and harassment may deter the majority of lawyers from engaging in weiquan lawyering, but these same pressures enrage and energize a few and push them to become more extreme. In addition, the suffering of radical lawyers can and does inspire younger lawyers to join the ranks. For example, lawyers who worked with Gao Zhisheng continue weiquan lawyering; and Teng Biao, Li Fangping and others, through their writings and legal practice, are inspiring the next generation. ${ }^{36}$ Young weiquan lawyers, including graduates of elite law schools and occasionally female graduates, joined the community both because of their admiration of their senior counterparts and their own commitment. ${ }^{37}$

A predominant goal of weiquan lawyering, in its moderate sense, is to draw people's grievances and disputes into proper legal channels and to settle them in accordance with legal procedure and rules. Instead of just grumbling about their grievances, people will have a forum to make their claims fairly and rationally with the assistance of lawyers. At the same time, legalizing conflict resolution, if successfully practised, can also help to judicialize politics by providing an alternative to sit-ins, demonstrations or hunger strikes. Occasionally, the government appears to be aware of law's pacifying functions and invites lawyers to deal with wayward petitioners and calm down angry people demonstrating in front of government offices. ${ }^{38}$

Frustration with the legal process detailed above, however, breeds radicalism. When legal remedies are too late, offer too little or are simply denied, frustration provides incentives for radical political-legal action. Unfortunately, such

35 Lawyer interview, September 2009, HK21.

36 Lawyer interviews, December 2006, BJ01; December 2008 and September 2009, HK04.

37 Lawyer interviews, April 2008, HK02 and HK03; September 2009, HK22 and HK23.

38 Lawyer interviews, April 2008, WH04; September 2009, HK13. 
frustration abounds. As one lawyer stated, half-jokingly, the whole legal establishment appears to be determined to block the legal channels and sabotage the legal process so that aggrieved people and their lawyers could start a revolution. ${ }^{39}$

\section{A radicalizing process}

At a certain point, some weiquan lawyers find it impossible to cope with the system and decide to take a more confrontational position vis-à-vis the government by setting themselves clearly apart from moderate weiquan lawyering.

Because of their initial success in providing pro bono legal assistance, they initially receive (usually central) government endorsement and support and become celebrities. Sooner or later, they start to attract the attention of foreign media, NGOs and governments and develop an international profile. They are invited on overseas trips and given funding to carry on their weiquan work. They become more ambitious and start to take on more contentious, sensitive cases. They continue to invest in developing new weiquan lawyering. As they move from individual case handling to larger government policies, they start to move closer to the so called "high voltage line" (gaoya xian 高压线) and become more critical of government policies. At that point, they experience negative government attention and notable frustration with the legal process.

As their weiquan activity progresses, the lawyers realize the limits of the legal framework they have tried to work within and the political restrictions they have tried to comply with. The space that the law permits for weiquan is indeed small and uncertain, and the politics of weiquan narrows the limited space even more. The further a lawyer walks on the weiquan path, the narrower the road becomes and the more restrictive is the environment. Legal assistance of this sort is useful in alleviating some individual suffering but it cannot go beyond scratching the surface in terms of policy changes. The more the lawyers provide legal assistance from their public conscience, the more they feel the need to go beneath the surface and to change the policies, institutions and the system. They then start to look for causes behind individual suffering and start to think in terms of national policy issues.

In jurisdictions where opposition politics is permissible, some radical lawyers have given up litigation in favour of more direct and broad-ranging political activism. Numbers of frustrated lawyers fighting for political causes in Taiwan, South Africa and elsewhere have lost faith in the courts and the legal system in general and turned to political mobilization and agitation. ${ }^{40}$

In the Chinese case where direct political challenge is impossible, lawyers and their clients are forced to use the legal mechanisms that they do not truly believe

39 Lawyer interview, September 2009, HK21.

40 Jane Kaufman Winn and Tang-chi Yeh, "Advocating democracy: the role of lawyers in Taiwan's political transformation"; Stephen Ellmann, "Law and legitimacy in South Africa"; and other articles in Law and Social Inquiry, Vol. 20, No. 2 (1995) 
in. In these circumstances, lawyers bring cases to courts not just to solve a problem but, very often, to expose abuses and challenge abusers. In defending house churches, lawyers have insisted on the constitutional protection of the freedom of speech and the freedom of religion ${ }^{41}$; in defending political dissidents charged with inciting the overthrow of government, they have demanded that prosecutors and judges specify the exact words or deeds which constituted the offences $^{42}$; and in defending falun gong practitioners, they have openly challenged the prosecution to prove that falun gong is legally an evil cult. ${ }^{43}$ As Pils says in her study of Gao Zhisheng, the work of lawyers like Gao has been to "expose and challenge the inner contradictions of the legal and political system ..."44 But this route is highly risky and any sign of real political challenge is nipped in the bud. This is the moment where some lawyers cross the "high voltage line." The initial support (or, more usually, indifference) from the legal community and government becomes hostility. The very weiquan activity which the government initially supported, or at least tolerated, is now suppressed in particular cases.

\section{Coping Strategies}

Avoidance

The majority of weiquan lawyers talk and act like politicians. They can talk passionately, but they also act rationally and with calculation. They are usually politically prudent and are prepared to compromise when necessary. Most will not directly confront the government if more moderate opportunities present themselves.

Lawyers have developed different ways to avoid potential confrontation, and all say they want to do their work without unnecessarily provoking the government. There is a high voltage line between permissible and "prohibited" lawyering, and lawyers, even the radical ones, are cautious not to cross the line, which is less visible and harder to detect in an authoritarian state such as China. This is particularly true in cases relating to what are perceived by government to be the vital interests of the state, a state with a weak legal system and lacking real rule of law. Legal provisions provide little guidance for lawyers. It is administrative fiat, not law, which determines where a line is drawn and whether it has been crossed. Party and government officials make a determination according to political necessity - or expediency. The elasticity of the high voltage line and the risks arising when it is crossed have made weiquan lawyering in political and sensitive cases particularly dangerous.

41 Lawyer interview, June 2007, BJ08.

42 Lawyer interview, December 2008, HK11; NGO interview, April 2009, HK02.

43 Lawyer interviews, September 2009, HK22 and HK23.

44 Eva Pils, "Asking the tiger for his skin: activism in China," Fordham International Law Journal, No. 30 (2007), p. 1209. 
But where there is risk, there is opportunity. The fact that a line exists, as vague and fluid as it is, not only indicates the possibility but legitimizes a degree of political lawyering. The lack of definition of the high voltage line also works against officials: as long as legal practice is justifiable, it is difficult for the government to impose severe political restrictions openly and legitimately. Unless the government is prepared to trample on the law in the open, it has to pay something beyond lip-service to the rights of lawyers in the operation of the legal process. For example, the government cannot openly demand that lawyers do not actively defend political dissidents, religious cults or cases that may affect social stability. Instead, it can only smuggle in political restrictions through harassing lawyers or their firms or by taking pre-emptive measures to stop the potential line-crossers. The government is, therefore, less powerful than one might think.

The elasticity of the high voltage line is thus a double-edged sword: it allows the government to expand the prohibitive zone at times, but it also gives opportunities for lawyers to push the limit. It is often said that the bottom line for lawyers is not to challenge the leadership position of the CCP and the socialist system. But what exactly this bottom line entails is difficult to articulate. The CCP is adapting itself to the changing international and domestic environments, and socialism in China is a fluid concept subject to fundamentally conflicting interpretations. The party/state can abuse this fluidity by constantly moving the goal posts according to its immediate political interest. But there are lawyers and others who also exploit this flexibility by pushing and redefining the same fluid outer limits to create more political space through law and other means.

Lawyers have to develop a particular sense of understanding of how and when a line has been crossed. As one weiquan lawyer said, many factors are in place in any particular case, it is very context-dependent. A line is drawn differently in different types of cases and it may also shift over time. It may be drawn by different levels of government according to the perceived importance of the relevant cases. ${ }^{45}$ For instance, in the illegal brick kilns cases involving slave labour, the lawyers involved believed that there was a systemic effort by central authorities to limit the involvement of lawyers from Beijing: the same restrictions were imposed on the same type of cases filed with courts in different jurisdictions. But in other cases, it is the local government which decides where exactly a line lies and when a lawyer has crossed it. There is little central planning and the standard applied varies greatly from one locality to another. ${ }^{46}$

Lawyers develop certain coping strategies. Some moderate lawyers are confident of their ability to push the limit without crossing the line. Weiquan lawyers all claim that their bottom line is their ability to convert an event into a legal case. There is no line and thus no limit if the case can be framed as a legal issue, especially if the case can be accepted by the court. Once an event is framed successfully as a legal case, lawyers are more or less free to bring it back to the public

45 Lawyer interviews, March 2008, BJ11 and BJ12.

46 Lawyer interviews, April 2008, HK01 and HK02; December 2008, HK04. 
sphere and ultimately channel it into the political process (as it operates in China): a legal case makes it legitimate for lawyers to organize academic discussion over the case and campaign for support in the media by publicizing both the case and the academic discussion.

But lawyers may miscalculate the risk, overestimating their own ability to predict the location of the line. Some of the first 18 lawyers who volunteered their legal services in public for the Tibetans to be prosecuted for involvement in the riots in March 2008 actually thought participation would not be particularly risky, and were surprised by the strong reaction of the government. ${ }^{47}$ Lawyer Li Jianqiang 李建强 advised younger weiquan lawyers that the best way to avoid persecution while working as a weiquan lawyer is to do it without talking about it. Yet he conceded that it was almost impossible to be a weiquan lawyer without expressing one's critical stance. He lost his practising licence because he could not help being vocal in doing weiquan work. It was the unjust environment that forced him to speak out. ${ }^{48}$

Less moderate lawyers tend to be more doubtful of their ability to understand just where the line is drawn. They are well aware that the government may find excuses to harass and punish them, and therefore become cautious not only in their professional life but also in their daily life. While aggressive in the court room in suing local government departments, barefoot lawyer Zhou Guangli 周广立 was actually a "model villager" and well-behaved, to the extent that he would never violate any rules of the government, even the apparently unlawful ones. He did so only to prevent giving the government any excuse for harassment. ${ }^{49}$ Another lawyer described his underground working strategy:

In carrying out investigation, we are secretive. We almost never use mobile phones, and simply work through our [personal] network ... our experiences are that ... [the police] monitor our telephone conversations, set traps and then detain us or use thugs under their control to attack us. We don't stay at one place continuously, and we don't go to bars or KTV. We don't give them any opportunities. We are vigilant as rabbits; we rarely reveal our true identity. ${ }^{50}$

\section{Fame as a self-protection mechanism}

Being radical and keeping a high profile may, however, be the best protection a weiquan lawyer can have. The criminal justice system treats suspects and their lawyers differently according to their political and economic status, and there is a large degree of discretion built into the criminal process. Lawyers with political status and more institutional support are treated more leniently than an

47 "Tibet is to try suspected rioters, weiquan lawyers propose to offer legal assistance," Ming bao, 6 April 2008, p. A03.

48 "An interview with prominent weiquan lawyer Li Jianqiang," Minzhu Zhongguo, 22 November 2007, http://www.minzhuzhongguo.org/Article/wq/200711/20071122113253.shtml, accessed 18 February 2009.

49 Ying Xing, "Welcoming the law to the countryside' or 'approaching justice': a case study of Chinese rural 'barefoot lawyers'," Zhengfa luntan (Tribune of Political Science and Law), No. 1 (2007), p. 79.

50 Email communication with a weiquan lawyer in March 2008 
ordinary weiquan lawyer. The best example is Guo Feixiong 郭飞雄 in the Taishi village election case. The police in Guangdong 广东 named three "black hands" behind the recall campaign: Lu Banglie 吕邦列, Ai Xiaoming 艾晓明 and Guo Feixiong. But Guo was the only one singled out for investigation and harassment. ${ }^{51}$ The only reasonable explanation for this discriminatory prosecution was that $\mathrm{Lu}$ was a deputy of a local people's congress and Ai was a professor in the prestigious Sun Yat-Sen University (Zhongshan Daxue 中山大学). Guo's protest through a hunger strike in a detention centre did not earn him better treatment..$^{52}$

People like Guo who wish to carry on doing sensitive weiquan work without strong institutional support need to make a name for themselves so that they are strong enough to resist government harassment and prosecution. It is the reputation and standing of particular weiquan lawyers, not the nature of their acts, which largely determines the seriousness of any government reaction. The understanding is that the government treats well-known dissidents with caution and less-known ones with more brutality. Weiquan lawyers can point to numerous examples. According to Li Jianqiang, well-known writer Du Daobin 杜导斌 received a suspended sentence, while little-known Luo Yongzhong 罗永忠 got three years' imprisonment for virtually identical activities; Jiang Lijun 姜立军 was sentenced to four years' imprisonment for subversive internet speech, but his co-defendant, the famous "stainless steel mouse" (buxiugang laoshu 不锈钢 老鼠) Liu Di 刘荻, was not even prosecuted. Li attributes the different treatment to the differences in public reaction. ${ }^{53}$ The government wanted to prosecute all of them, but it was willing to compromise when public reaction became strong. Well-known figures attract more attention and stronger support from domestic and international communities than the less well-known. It is trite law among the weiquan community that young lawyers with a weiquan ambition need to stay low, collect their points and become more direct in challenging the government when they become "known." The lawyer mentioned above who preferred to work in secrecy admitted that working in such a way does not give him publicity and fame. The downside of this is that his punishment would probably be very harsh if the government lays its hands on him.

The question then becomes: how can one become "famous" so as to attract more domestic and international attention, particularly media attention, thus increasing the (political) cost of prosecution? The answer is: one has to stand out. For Li Jianqiang, this can be achieved by being vocal:

Being vocal means to make comments on every public event, including not only publishing articles on-line, but also making comments in influential media in China and overseas, such

51 Yang Ming, "Guo Feixiong who assisted Guangdong villagers was released after months of detention," Voice of America (Chinese), 27 December 2005, http://www.voafanti.com/gate/big5/www.voanews.com/ chinese/archive/2005-12/w2005-12-27-voa27.cfm, accessed 19 February 2009.

52 Liu Lu, Weiquan lushi: yige weixian de zhiye (Weiquan Lawyers: A Dangerous Profession) (Hong Kong: Chengzhong Bookstore, 2006), pp. 107-09.

53 Ibid. 
as Voice of America, Radio Free Asia, Radio Taiwan International and others; it also means to lead and organize as many signature campaigns as possible. In an era with advanced information technology, this method may give you instant fame. The authorities dare not to touch you once you have become internationally famous. ${ }^{54}$

But one has to be strategic and avoid standing at the front line of high-risk cases, at least not until one has achieved sufficient fame. Only true heroes rush in and sacrifice themselves for a cause. Li was both critical of and sympathetic towards weiquan lawyers who kept a certain distance from the line but at the same time remained vocal. ${ }^{55}$

Weiquan lawyers may not have a choice not to be vocal. Foreign media, NGOs and foreign governments have become principal supporters of the cause of weiquan lawyers in China. Facing high domestic pressure, lawyers have to seek assistance from outside to publicize the causes of their clients and their own suffering. But there is a danger of relying too heavily on foreign assistance. The party/state is openly suspicious of any foreign connections and many of the foreign organizations are often seen as sworn enemies of the state.

Others in the broad weiquan community also expect weiquan lawyers to speak out. Those who play a leadership role and are regarded as important figures in China's weiquan community, such as Teng Biao, need to satisfy others' expectations and, therefore, have to retain a high profile in the public domain by expressing opinions on important issues. ${ }^{56}$

The government itself contributes notably to the radicalizing process by rewarding certain participants in the weiquan process who have taken drastic action such as using violence, suicide, sit-ins or demonstrations to make their points. Lawyers we interviewed offer numerous examples to illustrate the importance of taking drastic action to attract official attention and to receive a better deal from the government. The system clearly rewards "squeaking wheels" and this weakness is visible and invites more radicalism.

By being a "squeaking wheel" weiquan lawyers can occasionally achieve outcomes that other lawyers cannot. When a judge at the case filing section refused to accept a case that should have been accepted, a lawyer yelled and shouted at the judge and attracted a large audience. His "unruly" behaviour eventually forced the judge to reconsider his decision. ${ }^{57}$ When a court allocated a small room for a trial to prevent public attendance, the lawyer insisted on placing his desk right next to the judge so that there was enough space for the public. The court gave in and allocated a larger room for the trial. In this sense, the government (once again) has created its own challengers. ${ }^{58}$

\footnotetext{
54 Ibid. p. 108.

55 Ibid.

56 Lawyer interview, April 2008, HK01.

57 Lawyer interview, April 2007, SZ01.

58 NGO interview, April 2009, HK02.
} 


\section{Rationalizing weiquan lawyering}

To motivate themselves in a harsh environment, weiquan lawyers need not only spiritual support and inspiration but also hope that all their sacrifice is contributing to social change. Once lawyers became the driving force in the weiquan movement, it is not surprising that the movement became court-centric. Critics have rightly pointed out this heavy reliance on courts and the ultimate limits of litigation. It is telling that Zhang Sizhi, a prominent veteran human rights lawyer in China, has not won a case since 1979. Yet at the age of 80 he continues to try and protect rights through litigation. It is puzzling for many why so many lawyers continue to rely on litigation given the difficulty of winning a court case and the limited impact of a court victory.

But radical weiquan lawyers have different ways to rationalize their commitment and strategies. First, they create a distinct identity, defining themselves as lawyers independent of government and challenging the government. For them, moderate weiquan lawyers refuse to go beyond certain well-established mechanisms of representation, and are unwilling and unable to push the envelope. Radical weiquan lawyers consider that there is a difference between lawyering within the system and lawyering outside it.

For radical lawyers, moderate lawyers who avoid crossing the line merely decorate the system. Captured by the system, they perform as arranged and merely go through legal rituals as orchestrated by authorities. Their participation does little more than provide weak legitimacy for a repressive system - one which they should challenge. The defining characteristic of radical weiquan lawyers is their refusal to dance to the conventional tune. Instead, they insist on acting independently, raising questions that are embarrassing for the government and challenging for the courts. Aware that their submissions are not acceptable, they are willing to take the risk to raise them to challenge the system as a whole. They use the court as a forum to exercise their free speech to discredit the court system and to challenge the political system.

Understandably, from the point of view of moderate lawyers, radical lawyers are typically not interested in making legal arguments on individual cases. Radical weiquan lawyers, they say, perform in courts, raising irrelevant, political arguments. They are unprofessional, sub-standard and may be ill-motivated in doing what they do. While the government is unreasonable in meting out penalties, radical weiquan lawyers have also behaved irrationally in unnecessarily provoking the government. Gao Zhisheng and other weiquan lawyers have been harshly criticized by their more moderate counterparts for their unnecessary grandstanding and provocative statements. ${ }^{59}$

Secondly, radical lawyers are confident that they are making important contributions. It can be easily said that lawyers are making a virtue out of necessity.

59 Liu Lu, "Lawyer Guo Guoting, about you, I feel regret," Liu Lu wenji (Collection of Liu Lu's Articles), 6 June 2005, http://www.boxun.com/hero/liulu/60_1.shtml, accessed 19 February 2009. 
Unlike in South Korea, South Africa or Taiwan in their democratic transitions, where lawyers, frustrated by the legal process, could opt for more risky yet more effective opposition politics, ${ }^{60}$ Chinese lawyers do not have that luxury. The CCP party/state does not pretend to be a constitutional democracy and it always criminalizes political parties harbouring even minimal claims to political power. Lawyers are therefore forced into the narrow legal channel where a limited tolerance of dissidence is exhibited. In the end, weiquan lawyers may have little choice except to resort to litigation in court - with notable political imagination. It is not the lure of litigation that explains the court-centric approach to weiquan lawyering but the lack of alternatives.

But weiquan lawyers are more positive about the role of a legal action in court, and, more generally, about the possibility of promoting political change through developing constitutionalism and the rule of law. Legal procedures may shape the evolving demands for rights and impart salience to a cause. A legal action, ironically, catalyses a movement by framing demands, developing a common purpose and forging a common group identity. Law and the legal rights it creates draw people from diverse backgrounds together in real or virtual space to discuss their common concerns. Law offers hope to people, like a magnet, drawing people towards it, especially the vulnerable groups who are less embedded in or tethered to the political system. Because of the discourse on legal rights, millions of otherwise isolated HB carriers found a common identity from their common experience of victimization. Because of regulatory caging, social associations were severely limited. But court litigation and the associated publicity draw together otherwise isolated individuals and diffuse groups.

Once in court, lawyers can make their legal claims as well as political statements. Even when their legal battles are defeated in court, they draw comfort from the knowledge that they are able to achieve a degree of success in the political arena. As one lawyer pointed out, he may have hardly won any case suing a government department in court, but in one case, almost immediately after a court decision in favour of the department was handed down, the officials in charge were removed or otherwise punished. So in substance, the government kept its "face" by rejecting a lawyer's case but then acted as the lawyer demanded. ${ }^{61}$ Most importantly, the lawsuit and the in-house discipline set a political "precedent" to guide local officials and deter future local abuses.

Court victory can be contagious; it affects others similarly situated. Cascade law-suits may start elsewhere using similar strategies. In the process, victims can imagine the impossible. There is cognitive transformation and reformation. Victory sparks hope, especially among lawyers, allowing people to see the vulnerability in the government's position.

One common criticism of weiquan lawyers in the legal community is that their often unnecessary provocation not only puts an end to their own careers but also

60 See articles in Law and Social Inquiry, Vol. 20, No. 2 (1995).

61 Lawyer interview, June 2007, BJ05. 
creates a repressive environment which makes every lawyer's work more difficult. It is commonly said that "when one person is ill, all the people are forced to take medicine." Affected weiquan lawyers disagree strongly, arguing forcefully that there may be a momentary repression immediately following their persecution, but ultimately persecuted lawyers create a larger breathing space for all. A prosecuted lawyer can push the outer limits of the system and may be successful in re-drawing the line. In this sense, the space for weiquan lawyering, as limited as it is, should not be taken for granted. It is the result of the sacrifice of lawyers such as Gao Zhisheng and many others. At the very least, the government through its prosecution puts a spotlight on its own unreasonable boundaries and hence lets the world know that the emperor is once more appearing with no clothes, thus turning the trial of dissidents into yet another test of the basic legitimacy of the regime itself.

In addition to seeing hope in their work that others would dismiss, weiquan lawyers also rationalize suffering, become de-sensitized to the suffering and normalize the extraordinary. They feel a sense of safety when political charges, such as contacting overseas hostile organizations, are routinely used against mainstream lawyers and the most innocuous rights defenders. They explain that the police brutality which is inflicted on them is something within their contemplation: they live a life in which police harassment and detention are regarded as "normal." They need a strong personality and thick skin to handle thuggish local government. They all have had countless encounters with security personnel and have developed special skills in dealing with them. One rights advocate described his dealing with security persons in charge of his cases as if he was talking about a paternalistic and nagging parent. ${ }^{62}$ Another lawyer blamed weiquan lawyers and other activists for their "unnecessary" provocation of security police, such as insulting them as the running dogs of the government. ${ }^{63}$ Similarly, another was able to develop a good understanding with officers assigned to monitor him to the degree that the officers promised to refer criminal cases to him. ${ }^{64}$ Other lawyers may have less pleasant experiences, but they clearly treat the monitoring and harassment in a comparatively casual manner. They take for granted experiences that are extraordinary for most other human beings.

The radical weiquan lawyering world is a rough one in which only the toughest can survive. Lawyers need to develop not only a commitment to rectifying injustice, but also a strong personality and a thick skin, in addition to the necessity to establish at least the basic financial capacity so that they (and their families) can live and survive. It requires great personal fortitude - and a degree of toughness to be a good weiquan lawyer at the grassroots level. Many of them are referred to as diaomin 习民 (unscrupulous citizens), but they call themselves persons with the guts to fight and a strong sense of justice. However, even for tough fighters, they

62 NGO interview, September 2008, HK01.

63 Lawyer interview, June 2007, BJ05.

64 Lawyer interview, December 2006, BJ04. 
need additional spiritual support to sustain themselves. It is perhaps not surprising that a large number of the strongest weiquan lawyers have turned to religion, particularly Christianity, for guidance and support, although they also claim that they have turned to Christianity to develop a moral foundation for China's future democracy. ${ }^{65}$

\section{Conclusion}

The general pool of politically experienced persons is being steadily expanded by the continued development of weiquan lawyering. There are more "older hands" to advise energized newcomers and for these newcomers to look up to. Veteran weiquan lawyers are acutely aware of the importance of identifying and nurturing younger, including female, lawyers to carry on the battle. As China proceeds with its uneasy political development, it is fair to expect that the widening pool of weiquan lawyers will have a greater shaping role in that process than anyone might have imagined ten or twenty years ago.

Numbers of lawyers transform themselves through their weiquan practice. They become more critical of government policies and pose more challenges to the political system. Generally, they manage to do this still "within that system" (if only just). And they constantly learn new and more innovative ways to do this based on their experience.

The government evolves and adapts at a much slower pace than lawyers want. The sad truth is that, as long as the system remains largely unchanged, this upward mobility process will continue. A few lawyers will rise up to challenge the political system; they will be frustrated and radicalized, and later persecuted for their effort to change the system too rapidly. Yet many others, fully aware of the potential risk and consequences involved, will still choose to follow the footsteps of their predecessors, hence maintaining the real regime-shaping potential of weiquan lawyering in China.

65 NGO interviews, August 2009, HK03; June 2007, BJ05. 